\title{
PERBEDAAN SKALA NYERI PADA PEMBERIAN TERAPI SHORTWAVE DIATHERMI DENGAN PENAMBAHAN TERAPI LATIHAN PADA PASIEN CALCANEUS SPURS DI RS. GRANDMED LUBUK PAKAM, TAHUN 2018
}

\author{
Isidorus Jehaman ${ }^{1}$, Indra Alamsyah ${ }^{2}$
}

\author{
Program Studi Fisioterapi \\ Fakultas Keperawatan dan Fisioterapi Institut Kesehatan Medistra Lubuk \\ Pakam \\ Email: dorusman1976@gmail.com
}

DOI: https://doi.org/10.35451/jkf.v1i2.154

\begin{abstract}
The most common cause cited for plantar heel pain is biomechanical abnoemalities that lead to pathologic stress to the plantar soft tissues. Localized nerve entrapment of the medial calcaneal or muscular branch off the lateral plantar nerve may be a contributing factor. Sample of 14 subjects were divided into two groups, each group consist of 7 people. Control Group treated with the addition of exercise therapy. Measuring the degree of pain was used Visual Analogue Scale. This study used an experimental study or quasi experiment with pre test and post test group design. Techniques sampling by Purposive Sampling. Data processing and analysis of data using paired sample t-test. Result: Obtained difference of pain scale shortwave diathermy with the addition of exercise theraphy to patients calcaneus spurs with a mean value after control group of 3.29 treathment with SD amounting to 1.113 and then a mean value after control group of 2.57 with SD 0.535 . There is the effect of a significant increase pain scale of shortwave diathermy with the addition of exercise therapy after statistical test result prove that the $p$ value $=0,021$ ( $p$ $<0,05)$. Conclusion : there is difference of pain scale in the provision shortwave diathermy with the addition of exercise theraphy to patient calcaneus spurs.
\end{abstract}

Keywords : Calcneus Spurs, Pain, Shortwave Diathermy, Exercise Theraphy

\section{PENDAhUlUan}

Tujuan pembangunan kesehatan nasional menurut Departemen keseshatan Republik Indonesia,2010 adalah meningkatnya kesadaran, kemauan dan kemampuan hidup sehat bagi masing-masing individu dalam mewujudkan peningkatan derajat kesehatan masyarakat dengan terciptanya masyarakat, bangsa dan Negara Indonesia yang adil makmur dan damai serta mendorong masyarakat untuk hidup dalam lingkungan dan perilaku hidup sehat, mempunyai kemampuan dalam menjangkau pelayanan kesehatan yang bermutu, serta memiliki derajat kesehatan masyarakat yang optimal.

Prevalensi calcaneus spurs di Amerika mencapai $11 \%$ dari populasi, tetapi calcaneus spurs tidak selalu disebabkan oleh terjadinya fascitis plantaris. Biasanya gejala ini terjadi pada satu kaki dengan presentasi antara 20-30\% pasien dengan kondisi fascitis 
plantaris. Calcaneus spurs merupakan salah satu gangguan yang sering terjadi pada usia muda dan pertengahan atau atlit dan kasus ini sering terjadi pada laki-laki dengan presentasi 40\% (Crirtensen, 2009).

Berdasarkan penelitian Menz et al (2008) mengatakan bahwa dari 216 orang dengan 140 perempuan dan 76 laki-laki dengan usia rata-rata 76 tahun bahwa dari 119 orang atau 55\% satu diantaranya memiliki plantar calcaneus dan 103 atau $48 \%$ satu diantaranya memiliki taji pada tendon Achilles. Munculnya taji tidak mempunyai hubungan dengan jenis kelamin.

Berdasarkan penelitian bahwa 7,9\% dari $95 \%$ menderita calcaneus spurs yang disebabkan karena osteoarthritis dan 4,6 dari $95 \%$ disebabkan karena pernah memiliki nyeri tumit sebelumnya. Pada umumnya manusia usia 45-70 tahun mengalami gangguan sendi pergelangan kaki berupa nyeri disertai kekakuan sendi sebagai gejala Calcaneus spurs. Keluhannya ini akan semakin bertambah berat seiring dengan bertambahnya usia seseorang.

$$
\text { Physiotherpy In Orthopedics }
$$
disebutkan : 40-60\% populasi pada usia di atas 35 tahun. Presentasi ini meningkat seiring dengan bertambahnya usia seseorang dengan presentasi mencapai $85 \%$ terjadi diatas umur 75 tahun.

Sedangkan menurut data jumlah pasien baru di RS. Grandmed Lubuk Pakam sejak April 2014-April 2015, Sebanyak 1790 orang, 600 penderita Low Back Pain, 200 cervical spondylosis, 180 kasus stroke, 180 kasus tenis elbow, 140 kasus CTS, 120 kasus Post Operasi, 100 kasus plantar faciitis, 95 kasus calcaneus spur, 80 kasus anak dan 60 kasus scoliosis dan 45 kasus lainnya seperti wellness dan baby massage.

Adapun pengurangan nyeri Calcaneus Spurs dengan modalitas SWD
(ShortWave

Diathermy)

dengan menggunakan energy elektromagnetik yang dihasilkan arus bolak balik dengan frekuensi tinggi. Di dalam tubuh medan magnetik ini akan menimbulkan efek panas pada jaringan yang akan menyebabkan vasodilatasi pembuluh darah (Miclovitz, 2009). Setelah pemberian SWD dilanjutkan dengan terapi latihan yang pelaksanaannya menggunakan latihan-latihan gerak tubuh baik secara aktif maupun pasif (Gardiner, 2011).

Banyak penderita yang sudah mengalami perubahan dengan modalitas tersebut namun peneliti ingin meneliti lebih dalam apakah perbedaan skala nyeri pada pemberian terapi SWD dengan penambahan Terapi Latihan Pada pasien Calcaneus Spurs. Tujuan penelitian ini adalah untuk mengetahui perbedaan skala nyeri pada pemberian SWD dengan penambahan Terapi Latihan pada pasien calcaneus spurs di RS. Grandmed Lubuk Pakam.

\section{METODE PENELITIAN}

Jenis Penelitian ini menggunakan quasi experiment dengan pendekatan control group pre-test \& post-test. 2006, dalam sastroasmoro dan Ismail, 2014). Dalam penelitian ini, peneliti membagi responden menjadi dua kelompok yaitu kelompok $A$ dan kelompok B. Kelompok A adalah kelompok yang hanya memperoleh terapi Short Wave Diathermy (SWD, selanjutnya disebut sebagai kelompok control, dan kelompok B adalah kelompok yang memperoleh Short Wave Diathermy (SWD) dengan penambahan Terapi Latihan Selanjutnya disebut sebagai kelompok intervensi. Penelitian dilakukan di RS. Grandmed Lubuk Pakam pada JanuariApril 2016.

Populasi dalam penelitian ini adalah seluruh pasien Calcaneus Spurs di RS. Grandmed Lubuk Pakam dan 
Jurnal Keperawatan dan Fisioterapi (JKF), e-ISSN: 2655-0830

Vol. 1 No.2 Edisi November 2018-April 2019

https://ejournal.medistra.ac.id/index.php.JFK

Received: 27 April 2019 :: Accepted: 28 April 2019 :: Published 29 April 2019

bersedia mengikuti program yang telah ditetapkan oleh terapis. Teknik pengambilan sampel dilakukan dengan menggunakan purposive sampling. Sampel pada penelitian ini adalah pasien Calcaneus Spurs yang berjumlah 7 orang dari kelompok kontrol dan 7 orang dari kelompok intervensi.

Pengumpulan data primer dilakukan dengan dengan wawancara, kuesioner dan pengamatan langsung sedangkan data sekunder diperoleh dari catatan rekam medis di RS. Grandmed Lubuk Pakam yaitu data tentang kunjungan pasien Calcaneus Spurs.

Data dianalisis untuk perhitungan bivariate pada penelitian ini menggunakan T- Test (Uji T) dengan tingkat kepercayaan $a=0,05(95 \%)$. Apabila nilai $p$ ( $p$ value $) \leq 0,05$ maka hipotesa penelitian ini diterima yaitu da perbedaan skala nyeri pada pemberian SWD dengan penambahan Terapi Latihan pada pasien calcaneus spurs.

\section{HASIL}

\section{A. Karakteristik Responden}

Karakteristik responden diamati meliputi umur, jenis kelamin, diamati meliputi umur, jenis kelamin, berat badan dan pekerjaan. Hasilnya disajikan pada tabel berikut:

Tabel 1.

Distribusi Karakteristik Responden

\begin{tabular}{|c|c|c|c|c|}
\hline \multirow[t]{2}{*}{ Karakteristik } & \multicolumn{2}{|c|}{$\begin{array}{c}\text { Kelompok } \\
\text { Kontrol }\end{array}$} & \multicolumn{2}{|c|}{$\begin{array}{l}\text { Kelompok } \\
\text { Intervensi }\end{array}$} \\
\hline & $f$ & $\%$ & $f$ & $\%$ \\
\hline \multicolumn{5}{|l|}{ Umur } \\
\hline $40-50$ & 4 & 57,1 & 2 & 28,6 \\
\hline $51-60$ & 3 & 42,9 & 5 & 71,4 \\
\hline Total & 7 & 100,0 & 7 & 100,0 \\
\hline \multicolumn{5}{|l|}{ Jenis } \\
\hline Kelamin & 2 & 28,6 & 4 & 57,1 \\
\hline Laki-laki & 5 & 71,4 & 3 & 42,9 \\
\hline \multicolumn{5}{|l|}{ Perempuan } \\
\hline Total & 7 & 100,0 & 7 & 100,0 \\
\hline \multicolumn{5}{|l|}{ Berat Badan } \\
\hline$\leq 60 \mathrm{Kg}$ & 6 & 85,7 & 4 & 57,1 \\
\hline$>60 \mathrm{Kg}$ & 1 & 14,3 & 3 & 42,9 \\
\hline Total & 7 & 100,0 & 7 & 100,0 \\
\hline \multicolumn{5}{|l|}{ Pekerjaan } \\
\hline Wiraswasta & 2 & 28,6 & 5 & 71,4 \\
\hline
\end{tabular}

\begin{tabular}{|c|c|c|c|c|c|}
\hline IRT & & 4 & 57,1 & 1 & 14,3 \\
\hline PNS & & 1 & 14,3 & 1 & 14,3 \\
\hline & Total & 7 & 100,0 & 7 & 100,0 \\
\hline
\end{tabular}

Tabel 1 di atas menunjukkan bahwa jumlah responden berdasarkan umur pada kelompok control maka responden yang berumur 40-50 tahun sebanyak 4 orang $(57 \%)$ serta yang berumur 51-60 tahun sebanyak 3 orang (43\%) sedangakn kelompok intevensi yang berumu 50-50 tahun sebanyak 2 orang $(28,6 \%)$ dan yang berumur 51-60 tahun sebanyak 5 orang $(71,4 \%)$.

Kemudian jumlah responden berdasarkan jenis kelamin pada kelompok control maka responden lakilaki sebanyak 2 orang $(28,6 \%)$ dan berjenis kelamin perempuan sejumlah 5 orang $(71,4 \%)$ sedangkan kelompok intervensi, responden laki-laki sebanyak 4 orang $(57 \%)$ dan responden berjenis kelamin perempuan sebanyak 3 orang $(43 \%)$.

Kemudian karakteristik responden berdasarkan pada kelompok control maka responden dengan berat badan seberat ? $60 \mathrm{~kg}$ sebanyak 6 orang $(85,7 \%)$ dan responden degan berat badan seberat ? $60 \mathrm{~kg}$ sebanyak 1 orang $(14,3 \%)$ sedangkan kelompok intervensi maka responden dengan berat badan seberat ?60 kg sebanyak 1 orang (42,9\%). Sedangkan jumlah karakteristik responden berdasarkan pekerjaan kelompok control maka responden dengan pekerjaan wiraswasta sebanyak 2 orang $(28,6 \%)$, ibu rumah tangga sejumlah 4 orang $(57,1 \%)$ dan pegawai negeri sipil (PNS) sejumlah 1 orang $(14,3 \%)$ sedangkan intervensi maka jumlah responden dengan pekerjaan wirasuasta sebanyak 5 orang $(71,4 \%)$, ibu rumah tangga sebnayk 1 orang $(14,3 \%)$, PNS sejumlah 1 orang $(14,3 \%$.

\section{B. Intensitas Skala Nyeri Sebelum Dan Sesudah Dilakukan Intervensi I Pada Pasien}


Jurnal Keperawatan dan Fisioterapi (JKF), e-ISSN: 2655-0830

Vol. 1 No.2 Edisi November 2018-April 2019

https://ejournal.medistra.ac.id/index.php.JFK

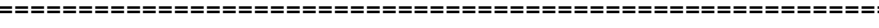

Received: 27 April 2019 :: Accepted: 28 April 2019 :: Published 29 April 2019

\section{Calcaneus Spurs}

Gambaran intensitas skala nyeri Sebelum dan Sesudah dilakukan intervensi kelompok control pada pasien calcaneus spurs disajikan pasa tabel 2 berikut:

Tabel 2

Distribusi Intensitas Skala Nyeri Responden Sebelum Dan Sesudah Dilakukan Intervensi Kelompok Control Pada Pasien Calcaneus Spurs

\begin{tabular}{lccccc}
\hline Kelompok & $\begin{array}{c}\text { Mea } \\
\mathbf{n}\end{array}$ & $\mathbf{n}$ & SD & $\begin{array}{c}\text { Min- } \\
\text { Max }\end{array}$ & $\mathbf{9 5} \mathbf{~ C l}$ \\
\hline Sebelum & 4,86 & 7 & 0,690 & $4-6$ & $4,22-5,50$ \\
Sesudah & 3,29 & 7 & 1,113 & $4-6$ & $2,26-4,31$ \\
\hline Selisih & $\mathbf{1 , 5 7}$ & & & & \\
\hline
\end{tabular}

Tabel 2 di atas menunjukkan bahwa rerata pengukuran nyeri pada responden sebelum kelompok Kontrol adalah 4,86 (95\% CI : 4,22-5,50) dengan standar deviasi (SD) 0,690. Pengukuran nyeri terendah 4 dan tertinggi 6. Dari hasil enstimasi interval dapat disimpulkan bahwa 95\% diyakini rerata pengukuran nyeri sebelum diberikan SWD adalah diantara 4,225,50 sedangkan rerata pengukuran nyeri pada responden sesudah kelompok control adalah 3,29 (95\%CI : 2,26-4,31) dengan standar deviasi 1,113 . Pengukuran nyeri terendah 4 dan tertinggi 6, dari hasil estimasi interval dapat disimpulkan bahwa $95 \%$ diyakini rerata pengukuran nyeri sesudah kelompok kontrok adalah diantara 2,264,31 , dengan selisih mean adalah 1,57 .

C. Perbedaan Rerata Nyeri Sebelum dan Sesudah Pemberian SWD (Kelompok Kontrol) Pada Pasien Calcaneus Spur

Perbedaan rerata nyeri sebelum dan sesudah pemberian SWD pada pasien Calcaneus Spur disajikan pada tabel 3 berikut ini:

\section{Tabel 3}

Perbedaan Rerata nyeri dengan Pemberian SWD (Kelompok Kontrol) Pada Pasien Calcaneus Spurs

\begin{tabular}{lcccc}
\hline $\begin{array}{c}\text { Rerata } \\
\text { Nyeri }\end{array}$ & Mean & n & SD & p.value \\
\hline $\begin{array}{l}\text { Sebelum } \\
\text { dan }\end{array}$ & 1,571 & 7 & 1,077 & 0,000 \\
Sesudah & & & & \\
\hline Selisih & $\mathbf{0 , 8 5 7}$ & & & \\
\hline
\end{tabular}

Dari tabel 3 diatas menunjukkan bahwa perbedaan skala nyeri sebelum dan sesudah perlakuan kelompok control dengan SWD pada pasien calcaneus spurs dengan nilai mean 1,571, Standard Deviasi 0,535, 95\%, selisih 0.857. Berdasarkan hasil uji statistic dengan menggunakan uji dependent sample t-test paired t-test penelitian ini diterima yang berarti ada perbedaan yang signifikan dalam pemberian SWD sebelum dan sesudah dalam penurunan skala nyeri pada pasien calcaneus spurs.

Tabel 4

Perbedaan Skala Nyeri dengan SWD dengan Penambahan Terapi Latihan pada Pasien Calcaneus Spurs di RS. Grandmed Lubuk Pakam

\begin{tabular}{lcccc}
\hline $\begin{array}{c}\text { Rerata } \\
\text { Nyeri }\end{array}$ & Mean & n & SD & $\begin{array}{c}\text { p.valu } \\
\text { e }\end{array}$ \\
\hline $\begin{array}{l}\text { Sebelum } \\
\text { dan }\end{array}$ & 2,714 & 7 & 0,488 & 0,001 \\
Sesudah & & & & \\
\hline Selisih & $\mathbf{0 , 8 5 7}$ & & & \\
\hline
\end{tabular}

Dari tabel 4 diatas menunjukkan bahwa perbedaan skala nyeri sebelum dan sesudah perlakuan kelompok Intervensi dengan SWD dengan penambahan Terapi Latihan pada pasien calcaneus spurs dengan nilai mean 2.714, Standard Deviasi 0.488, selisih 0,857 . Berdsarkan hasil uji statistic dengan menggunakan uji dependent sample t-test paired t-test menunjukkan bahwa $p$ value yaitu 0,001 yang berarti pValue $<0,05$. Maka hipotesa dalam penelitian ini diterima yang berarti ada perbedaan yang signifikan dalam pemberian SWD dengan penambahan terapi latihan sebelum dan sesudah dalam penurunan skala nyeri pada pasien calcaneus spurs. 
Jurnal Keperawatan dan Fisioterapi (JKF), e-ISSN: 2655-0830

Vol. 1 No.2 Edisi November 2018-April 2019

https://ejournal.medistra.ac.id/index.php.JFK

Received: 27 April 2019 :: Accepted: 28 April 2019 :: Published 29 April 2019

Tabel 5

Perbedaan Rerata Skala Nyeri Sesudah Swd Dengan Sesudah Pemberian SWD dengan Penambahan Terapi Latihan Pada Pasien Calcaneus Spurs.

\begin{tabular}{lllll}
\hline Rerata Nyeri & Mean & n & SD & p.value \\
\hline $\begin{array}{l}\text { Nilai VAS } \\
\text { sebelum dan } \\
\text { sesudah }\end{array}$ & & & & \\
$\begin{array}{l}\text { konytrol-nilai } \\
\text { VAS sesudah } \\
\text { intervensi }\end{array}$ & 0,714 & 14 & 0,951 & 0,021 \\
\hline
\end{tabular}

Dari tabel 5 diatas menunjukkan bahwa perbedaan rerata skala nyeri sesudah perlakuan kelompok control dengan SWD dan sesudah pelakuan kelompok intervensi dengan SWD dengan penambahan Terapi Latihan pada pasien calcaneus spurs dengan nilai mean 0.714, Standard Deviasi 0.951. Berdasarkan hasil uji statistic dengan menggunakan uji dependent sampel t-test/ paired t-test menunjukkan bahwa $p$ value yaitu 0,021 yang berarti pvalue $<0,05$. Maka hipotesa dalam penelitian ini diterima yang berarti ada perbedaan yang signifikan dalam pemberian susudah SWD dengan penambahan terapi latihan dalam penurunan skala nyeri pada pasien calcaneus spurs.

\section{PEMBAHASAN}

\section{A. Karakteristik Responden}

Jumlah responden berdasarkan umur pada kelompok control dengan perlakuan SWD maka mayoritas responden yang berumur 40-50 tahun sebanyak 4 orang $(57,1 \%)$, sedangkan pada kelompok intervensi dengan perlakuan SWD dengan penambahan terapi latihan maka mayoritas yang berumur 51-60 tahun sebanyak 5 orang $(71,4 \%)$. Hal tersebut sesuai dengan teori yang ada bahwa proses penuaan sangat berperan pada proses terjadinya calcaneus spurs (Cluett,2014).

Sedangkan pada jenis kelamin kelompok control dengan perlakuan
SWD mayoritas responden dengan jenis kelamin perempuan sejumlah 5 orang $(71,4 \%)$ sedangkan kelompok intervensi SWD dengan penambahan Terapi Latihan maka mayoritas responden lakilaki sebanyak 4 orang $(57,1 \%)$. Hal ini diduga berhubungan dengan hormone estrogen dimana wanita dewasa memiliki masa tulanng yang lebih sedikit dari pada pria dewasa dan setelah menopause estrogen menghilang dengan cepat sehingga menyebabkan wanita lebih cepat kehilangan tulang dari pada pria dengan usia yang setara. Menghilangnya estrogen dengan cepat menyebabkan terjadinya peningkatan aktifitas osteoklas atau osteofita, berkurangnya aktifitas osteoblast, matriks tulang dan deposit kalsium tulang (Kamar, 2009). Kemudian karakteristik responden berdasarkan Berat Badan dengan perlakuan SWD dengan penambahan Terapi Latihan pada kelompok control maka mayoritas dengan berat badan seberat ?60 kg Sebanyak 6 Orang $(85,7 \%)$ dan kelompok intervensi maka mayoritas responden dengan berat badan ?60 kg sebanyak 4 orang $(57,1 \%)$.

Hal ini tidak mempengaruhi dalam proses terjadinya calcaneus spurs disebabkan hasil yang tidak signifikan. Karakteristik responden berdasarkan pekerjaan dengan SWD dengan penambahan Terapi Latihan pada kelompok control maka mayoritas dengan pekerjaan Ibu Rumah Tangga sebanyak 4 orang $(57,1 \%)$ dan kelompok intervensi maka jumlah responden dengan pekerjaan wiraswasta sebanyak 5 orang $(71,4 \%)$. Hal ini tidak mempengaruhi dalam proses terjadinya calcaneus spurs dikarenakan hasil yang yang tidak signifikan antara pekerjaan ibu rumah tangga dan wiraswasta.

\section{B. Skala Nyeri Pasien Calcaneus}


Jurnal Keperawatan dan Fisioterapi (JKF), e-ISSN: 2655-0830

Vol. 1 No.2 Edisi November 2018-April 2019

https://ejournal.medistra.ac.id/index.php.JFK

Received: 27 April 2019 :: Accepted: 28 April 2019 :: Published 29 April 2019

\section{Spurs Sebelum Dan Sesudah Diberikan SWD (Kelompok Kontrol)}

Berdasarkan hasil distribusi penelitian didapatkan bahwa nilai mean sebelum perlakuan kelompok control sebesar 4,86 dan nilai SD sebesar 0,690 . Sedangkan Distribusi kategori skala nyeri sesudah perlakuan control dengan nilai mean sesudah perlakuan kelompok control sebesar 3,29 dan nilai SD sebesar 1,113. Hasil uji statistic dengan menggunakan uji dependent sample t-test paired t-test menunjukkan bahwa $p$ value yaitu 0,000 yang berarti pValue $<0,05$. Maka hipotesa dalam penelitian ini diterima yang berarti ada perbedaan yang signifikan dalam pemberian SWD sebelum dan sesudah dalam penurunan skala nyeri pada pasien calcaneus spurs.

Pemanasan dengan derajat yang ringan sangat efektif untuk mengurangi nyeri yang mana dipengaruhi oleh efek seudatif (efek rasa enak atau nyaman) dalam jaringan sensoris. Hal ini terjadi karena pada jaringan yang mengalami nyeri akan membuang sisa-sisa etabolisme dan meningkatkan sirkulasi darah yang dapat menembus daerah nyeri, kemudian membantu dalam penurunan nyeri sehingga dapat berkurang (Scott,2010)

Efek panas yang dihasilkan oleh SWD selain dapat mengurangi nyeri, tetapi juga dapat memperlancar sistem sirkulasi darah, merileksasikan otot, serta mengurangi spasme. Berkurangnya spasme dan rileksasi otot, maka akan lebih mudah unutk melakukan gerakan (Scott,2010).

\section{Skala Nyeri Pasien Calcaneus \\ Spurs Sebelum Dan Sesudah Diberikan Swd Dengan Penambahan Terapi Latihan (Kelompok Intervensi).}

Berdasarkan hasil distribusi penelitian didapatkan skala nyeri responden calcaneus spurs sebelum perlakuan pada kelompok intervensi dengan nilai mean sebelum perlakuan kelompok intervensi sebesar 5,29 dan nilai SD sebesar 0,756. Sedangkan distribusi kategori skala nyeri sesudah perlakuan elompok intervensi dengan nilai mean sesudah perlakuan kelompok intervensi sebesar 2,57 dan nilai SD sebesar 0,535. Hasil uji statistic dengan menggunkan uji dependent sample $\mathrm{t}$ test paired t-test menunjukkaan bahwa $p$ value yaitu 0,001 yang berarti pValue $<0,05$. Maka hipotesa dalam penelitian ini diterima yang bearti ada perbedaan yang signifikan dalam pemberian SWD dengan penambahan Terapi Latihan sebelum dan sesudah dalam penurunan skala nyeri pada pasien calcaneus spurs.

Hasil penelitian ini sejalan dengan teori yang dituliskan oleh Greene (2007) mengatakan bahwa terapi latihan, memberikan pengaruh besar pada tubuh secara keseluruhan, antara lain dapat memperlancar aliran darah, aliran limpa, serta dapat merangsang dan memperlancar sistem pencernaan. Prinsip yang mendasari penurunan nyeri dengan tehnik SWD dan Terapi Latihan terletak pada fisiologi system saraf otonom. Pada saat terjadi pelepasan efek panas akan merangsang saraf sehingga menyebabkan vasokontriksi yang akhirnya dapat meningkatkan metabolism, melancarkan sirkulasi darah, merileksasikan otot sehingga spasme dan nyeri akan berkurang (Baker et al,2008).

Kemudian dengan memberikan terapi latihan dapat mempercepat proses penyembuhan dan pemulihan suatu penyakit tertentu. Terapi latihan yang diberikan pada dasarkan merupakan salah satu modalitas fisioterapi yang yang dilaksanakan dengan memakai metode latihan-latihan baik latihan aktif maupun latihan pasif. Karena penurunannya suatu fungsi dapat menghambat kemampuan dirinya 
Jurnal Keperawatan dan Fisioterapi (JKF), e-ISSN: 2655-0830

Vol. 1 No.2 Edisi November 2018-April 2019

https://ejournal.medistra.ac.id/index.php.JFK

Received: 27 April 2019 :: Accepted: 28 April 2019 :: Published 29 April 2019

secara mandiri.

Tujuan terapi latihan ini adalah untuk meningkatkan kapasitas fisik penderita, seperti meningkatkan kekuatan otot dan meningkatkan Luas Gerak Sendi, serta dapat menigkatkan aktifitas fungsionalnya sehari-hari tanpa bantuan orang lain/secara mandiri (Heri,2011).

Adapun efek fisiologis SWD yaitu meningkatkan metabolism sel-sel local, meningkatkan elastisitas jaringan ikat 5-10 kali lebih baik dari pada jaringan collagen kulit, otot, tendon, ligamentum dan kapsul sendi yang disebabkan oleh penurunan viskositas matrik jaringan, dan menurunkan tonus otot lewat normalisasi nosisensorik. Sedangkan efek terapeutik SWD adalah meningkatkan proses reparasi jaringan secara fisiologis, mengurangi nyeri, normalisasi tonus otot melalui efek seudatif, perbaikan sistem metabolism dan dapat meningkatkan elastisitas jaringan (Ig Sujatno, 2012).

\section{Perbedaan Perbedaan skala nyeri SWD dengan penambahan Terapi Latihan pada pasien calcaneus spurs di RS. Grandmed Lubuk Pakam.}

Dari hasil penelitian mengenai perbedaan skala nyeri SWD dengan penambahan Terapi Latihan pada pasien calcaneus spurs yaitu responden yang diberikan SWD (Kelompok Kontrol) didapatkan hasil uji statistic dengan menggunakan uji dependent sample ttest menunjukkan bahwa nilai mean/rerata sebelum pemberian SWD yaitu 4,86, nilai mean/rerata nyeri responden calcaneus spurs sesudah diberikan SWD yaitu 3,29, dan selisih rerata sebelum dan sesudah diberikan SWD yaitu 1.571. Berdasarkan hasil uji statistic dengan menggunakan uji dependent sample t-test/paired t-test menunjukkan bahwa pValue yaitu 0,000 yang berarti $\leq 0,05$.

Sedangkan Responden yang diberikan SWD dan penambahan Terapi Latihan didaptkan hasil uji statistic dengan menggunakan uji dependent sample t-test/paired t-test menunjukkan bahwa nilai mean/rerata seblum pemberian SWD dengan penambahan Terapi Latihan yaitu 5,29, rerata nyeri responden calcaneus spurs sesudah diberikan SWD dengan penambahan Terapi Latihan yaitu 2,57, dan selisih rerata sebelum dan sesudah diberikan SWD dengan penambahan Terapi Latihan yaitu 2.714. Berdasarkan hasil uji statistic dengan menggunakan uji dependent sample $\mathrm{t}$-test/paired $\mathrm{t}$ test menunjukkan bahwa pValue yaitu 0,001 yang berarti $\leq 0,05$.

Perbedaan Skala nyeri sesudah perlakuan kelompok control dengan SWD dan sesudah perlakuan kelompok intervensi dengan SWD dengan penambahan Terapi Latihan Pada pasien calcaneus spurs. Dari hasil penelitian mengenai perbedaan skala nyeri sesudah perlakuan kelompok kontol dengan SWD dan sesudah perlakuan kelompok intervensi dengan SWD dan penambahan Terapi Latihan pada pasien calcaneus spurs dengan nilai mean 0.714, Standar Deviasi 0.951, 95\% CI Lower -0.165 dan Upper 1.594. Berdasarkan hasil uji statistic dengan menggunakan uji dependent sample ttest paired t-test menunjukkan bahwa $p$ value yaitu 0,021 yang berarti pValue $<0,05$. Maka hipotesa dalam penelitian ini diterima yang berarti ada perbedaan yang signifikan dalam pemberian sesudah SWD dan penambahan Terapi Latihan. Hasil analisa statistic penelitian ini dapat disimpulkan bahwa dalam penurunan nyeri dengan SWD dan penambahan Terapi Latihan lebih efektif dibandingkan dengan SWD pada pasien calcaneus spurs di RS. Grandmed Lubuk Pakam.

Adapun efek panas yang dihasilkan oleh SWD selain dapat mengurangi nyeri SWD juga dapat memberikan rileksasi 
pada otot sehingga dapat mengurangi spasme otot, memperlancar sirkulasi darah. Kondisi ini akan mempermudah dalam melakukan gerak-gerakan dan aktifitas sehari-hari (Scott, 2010). Sedangkan efek terapi latihan adalah meningkatkan kekuatan dn daya otot, memperbaiki keseimbangan otot,, meningkatkan koordinasi gerakan, memperbaiki kondisi umum penderita kemudian dapat mengurangi gelaja dengan cara membuat saraf bergerak bebas, mengurangi perlengketan, fasilitasi aliran darah balik vena dan menghilangkan oedema.

Melalui teknik ini, dapat membantu oksigenasi saraf peroneus pada area pergelangan kaki, terjadi penurunan tekanan didalam perineum, penurunan tekanan calcaneal, pengurangan nyeri iskemik (Atya el al., 2011).

\section{KESIMPULAN}

Berdasarkan hasil uji statistic dari pembahasan tersebut diatas dapat disimpulkan bahwa perbedaan skala nyeri pada pemberian SWD dengan penambahan Terapi Latihan pada pasien calcaneus spurs adalah dengan distribusi kategori skala nyeri sesudah perlakuan kelompok control dengan nilai mean sesudah perlakuan kekelompok konreol sebesar 3,29 dan nilai SD sebesar 1,113. Hail uji statistic dengan menggunakan uji dependent sample ttest paired t-test menunjukkan bahwa $p$ value yaitu 0,000 yang berarti pValue $<0,05$.

Sedangkan distribusi kategori skala nyeri sesudah perlakuan kelompok intervensi dengan nilai mean sesudah perlakuan kelompok sebesar intervensi sebesar 2,57 dan nilai SD sebesar 0,535 . Hasil uji statistic menggunakan uji dependent sampel t-test paired ttest menunjukkan bahwa $p$ value yaitu 0,001 yang berarti pValue $<0,05$.

Kemudian sesudah perlakuan kedua kelompok didapati nilai mean 0.714, Standard Deviasi 0.951, 95\% CI Lower 0.165 dan Upper 1.594. Berdasarkan hasil uji statistic dengan menggunakan uji dependent sample t-test paired t-test menunjukkan bahwa $\mathrm{p}$ value yaitu 0,021 yang berarti pValue $<0,05$. Maka hipotesa diterima yang berarti ada perbedaan skala nyeri pada pemberian SWD dengan penambahan Terapi Latihan pada pasien calcaneus spurs di RS. Grandmed Lubuk Pakam

\section{SARAN}

1. Khususnya bagi Rumah sakit/klinik yang memiliki pasien calcaneus spurs diharapkan lebih mempertimbangkan prosedur yang tepat dalam mengurangi rasa nyeri pada pasien tentang perbedaan skala nyeri pada pemberian terapi SWD dengan penambahan Terapi Latihan pada kasus calcaneus spurs.

2. Diharapkan shortwave diathermy dan terapi latihan menjadi bahan ajar tambahan pada mahasiswa tentang penanganan fisioterapi pada penderita calcaneus spurs.

3. Diharapkan dapat menambah keilmuan dan wawasan fisioterapis dalam bidang fisioterapi khususnya pengurangan yeri pada pasien calcaneus spurs dan dapat dijadikan bahan acuan pembuatan SOP (Standard Operasional Prosedur) penanganan pasien calcaneus spurs.

4. Hendaknya peneliti berikutnya menggunakan jumlah sample yang lebih besar dari penelitian ini dan waktu penelitian yang lebih lama dari penelitian ini agar hasil yang didapat maksimal.

5. Hendaknya responden menghafal dan mencatat setiap arahan yang diperintahkan peneliti agar dapat dilakukan latihan dirumah.

\section{DAFTAR PUSTAKA}

Arovah
dasar 2010.
Olahraga. Yogyakarta:
Atya AM dan Mansour WT.
2011. Laser


versus Nerve and Tendon Gliding Exercise in Treating Calcaneus Spurs. Life Science Journal. Cairo: Departement of Basic Science, Faculty of Physical Theraphy.

Bora, 2010; Foot Pain and Impairtment, F. A Davis Company, Philadelphia.

Collins. 2011. 100 Question and Answer: Heel Pain. Penerbit: Elex Media Komputindo.

Crirtensen, 2009; Complate quide to Sport Injury_(How to reat Fractur, Bruises, Sprains, Strains, Dilocations, Head Injuries.

Depkes R.I. 2010. Sumber Fisis. Jakarta: Program Studi D III Universitas Kristen Indonesia.

Gardiner, S., (2011); Principles of Exercise Therapy, Thrid edition. Bell and Hymon Publisers, London.

Greene, 2007; Science and Medicine of Exercise and Sport, Harpes and Brothers Publisers, New York, hal. 36-62

Heri, 2011. Evaluasi Pelaksanaan Pemeriksaan Kesehatan Tenaga Kerja Di Indonesia, Surabaya James L Thomas, 2010; Evidance Base Practise of Physiotherapi

Kisner, C and Colby, L.A.2007. Therapeutic Exercise Foundatiouns and Techniques, $5^{\text {th }}$ Edition, Phyladelphia; F.A. Davis Company.

Kumar, 2009: Penceghan Nyeri Kaki, Jakarta

Nazir, 2003. Metodologi Penelitian. Jakarta; Ghalia Indonesia

Notoatmodjo S. 2010. Metodologi Penelitian Kesehat. Jakarta:

Rineka Cipta. 